\title{
Role of routine investigations in children presenting with their first febrile convulsion
}

\author{
N. RUTTER AND O. R. C. SMALES \\ From the Department of Child Health, University of Nottingham
}

SUMMARY To assess the role of routine investigations in children presenting with their first febrile convulsion, the results of investigations carried out in 328 children over a 2-year period were reviewed. Lumbar puncture was performed in $96 \%$ of cases and resulted in the detection of 4 cases of unsuspected meningitis, one of which was bacterial. 2 children had normal lumbar punctures on admission but developed meningococcal meningitis within 48 hours. Sugar, calcium, urea, and electrolyte estimations, and blood counts were commonly performed but were unhelpful. We suggest that lumbar puncture in those children presenting with their first febrile convulsion under the age of 18 months is the only useful routine investigation.

Febrile convulsions are a common clinical problem. About $3 \%$ of all children will have had a febrile convulsion by the time they reach school age, and many of these are admitted to hospital. But in spite of their frequent occurrence, there is little information available about the value of investigating children with their first febrile convulsion. In a recent survey in the United States paediatricians were questioned about the diagnostic studies which they ordered in such children and it was found that there was tremendous variation in the types of investigations performed and the frequency with which they were ordered. The authors stressed the need for examining the yield of commonly performed diagnostic procedures in this condition (Asnes et al., 1975).

We feel that there is a definite need to know which diagnostic tests performed in children with their first febrile convulsion are likely to be helpful and which are unlikely to be useful. Such knowledge is likely to benefit the child himself, the junior medical staff who carry out the procedures, and the laboratory staff who perform the tests.

\section{Method}

Over a 2-year period, from January 1974 to December 1975, 328 children were admitted to Nottingham Children's Hospital with their first febrile convulsion. The results of those investigations which were routinely performed at the time of admission were reviewed to determine the yield of abnormal results,

Received 7 June 1976 and an attempt was made to assess the usefulness of each investigation. For some years lumbar puncture has been performed routinely in all children presenting at this hospital with their first febrile convulsion, regardless of the absence of signs of meningitis or the presence of a definite cause of infection (e.g. otitis media or tonsillitis). Other investigations are performed at the discretion of the doctors.

Febrile convulsion has been defined for this study as a convulsion in association with a raised temperature on admission to hospital in a child with no signs of meningitis. No attempt was made to group the children by 'simple febrile convulsions' and 'epileptic seizures precipitated by fever' (Livingston, 1970). The mean age at presentation was $23 \cdot 5$ months and the number of children in each age group is shown in the Fig. 328 children (190 boys (58\%), 138 girls) were studied. 50 children $(15 \%)$ had convulsions which lasted for more than 15 minutes, and in 86 cases $(26 \%)$ a family history of febrile convulsions or epilepsy was obtained. The mean length of stay in hospital was 2.8 days (range 1-16 days). Table 1 gives the causes of the fever.

\section{Results}

The investigations performed were lumbar puncture, full blood count, blood glucose, calcium, urea, and electrolyte estimations (Table 2). Others, such as throat swabs and chest $x$-rays, were done when clinically indicated. Skull $x$-rays and electroencephalograms were not done. 


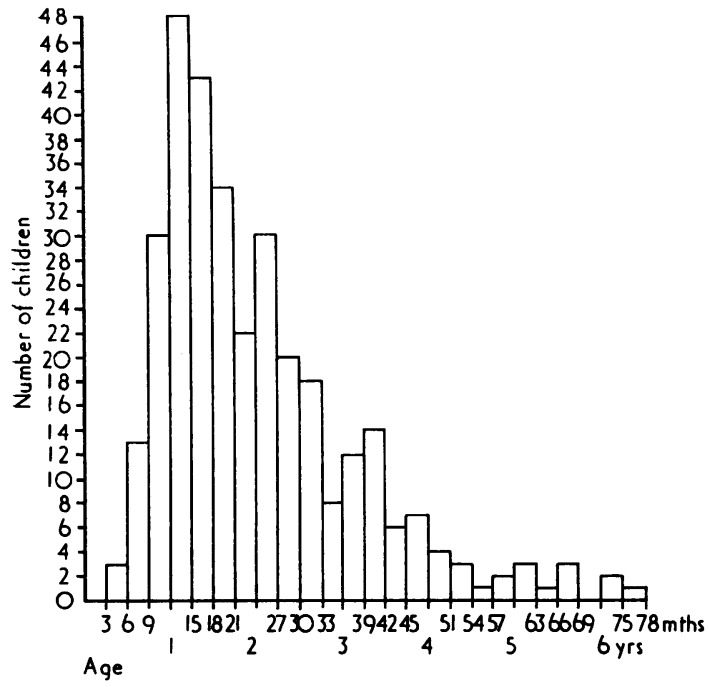

Fig. Age distribution of 328 children presenting with their first febrile fit.

Table 1 Cause of fever in 328 children with their first febrile fit

Upper respiratory tract infections (not specified)
Tonsillitis
Otitis media
Chest infections
Gastroenteritis
Meningitis
Urinary infections
Measles
Abscess
After triple immunization
Mumps
Cause of fever unknown
Total

Table 2 Frequency of commonly performed investigations in 328 children with their first febrile fit

\begin{tabular}{lll}
\hline & $\begin{array}{l}\text { No. of children in } \\
\text { whom investigations } \\
\text { were performed }\end{array}$ & $\%$ \\
\hline Lumbar puncture & 314 & 96 \\
Haemoglobin & 309 & 94 \\
White blood count & 309 & 94 \\
Blood glucose & 269 & 82 \\
Plasma calcium & 232 & 71 \\
Serum potassium & 166 & 51 \\
Serum sodium & 163 & 50 \\
Blood urea & 146 & 45 \\
\hline
\end{tabular}

Lumbar puncture. This was performed in 314 children $(96 \%)$ and unsuccessfully attempted in a further 4. In 310 cases the cerebrospinal fluid (CSF) examination was normal. However, 2 of the latter children remained febrile during hospital admission and later developed symptoms and signs of meningitis. A repeat lumbar puncture 36 hours later in one child (aged 2 years) and 48 hours later in the other (aged 13 months) showed meningococcal meningitis in both. Their initial convulsion did not differ in any way from that of the other children in the survey.

Four cases of meningitis were diagnosed by lumbar puncture in children who appeared to have had a febrile convulsion but had no physical signs suggesting meningitis (Table 3). 3 of these children had viral meningitis and the fourth, a 12-month-old boy, Haemophilus influenzae meningitis, successfully treated with ampicillin. He had had 3 convulsions on the day of admission lasting a few minutes, 10 minutes, and 15 minutes. In 3 of the children upper respiratory tract infection had been diagnosed before lumbar puncture was performed.

Haemoglobin. Hb was measured in 309 children $(94 \%) .5$ of these $(2 \%)$ were judged to be anaemic with a $\mathrm{Hb}$ of $1.0 \mathrm{~g} / \mathrm{dl}$ or more below the lower limit of normal for their age. Hb levels ranged from $7 \cdot 5$ $9 \cdot 3 \mathrm{~g} / \mathrm{dl} .3 \mathrm{had}$ blood films suggesting iron deficiency and were successfully treated with iron. The other 2 children, $\mathrm{Hb} 9.0$ and $9.3 \mathrm{~g} / \mathrm{dl}$, had normal films and were not followed up.

White blood count. 309 children $(94 \%)$ had total and differential white blood counts performed. In $107(35 \%)$ the total count was over $15000 / \mathrm{mm}^{3}$ $\left(15 \times 10^{9} / 1\right)$, and in $8(3 \%)$ it was below $6000 / \mathrm{mm}^{3}$ $\left(6.0 \times 10^{9} / 1\right)$. The total and differential white count did not appear to influence the decision to give or withhold antibiotics.

Blood glucose. This was measured in 269 children (82\%). Hyperglycaemia was common. 22 children $(8 \%)$ had blood glucose levels on admission in the range $151-200 \mathrm{mg} / 100 \mathrm{ml}(8 \cdot 4-11 \cdot 1 \mathrm{mmol} / \mathrm{l})$, and $17(6 \%)$ had levels above $200 \mathrm{mg} / 100 \mathrm{ml}$. The highest value was $450 \mathrm{mg} / 100 \mathrm{ml}(25 \mathrm{mmol} / \mathrm{l})$. The mean blood glucose was $120 \pm 50$ ( \pm 1 SD) $(6 \cdot 7 \pm 2 \cdot 8$ $\mathrm{mmol} / \mathrm{l})$. Only one child, a 6 year old who presented with a short febrile convulsion with tonsillitis, was found to be hypoglycaemic. Her blood glucose on admission was $30 \mathrm{mg} / 100 \mathrm{ml}(1 \cdot 7 \mathrm{mmol} / \mathrm{l})$, though she was not clinically hypoglycaemic. CSF glucose at the same time was $55 \mathrm{mg} / 100 \mathrm{ml}(3 \cdot 1 \mathrm{mmol} / \mathrm{l})$, and fasting blood glucose during the same admission was $75 \mathrm{mg} / 100 \mathrm{ml}(4 \cdot 2 \mathrm{mmol} / \mathrm{l})$. She has subsequently had one short convulsion in association with a fever, but otherwise remains well. All the other children had blood glucose levels above 65

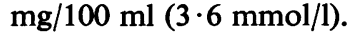


Table 3 Details of 4 children found to have meningitis on routine lumbar puncture (LP)

\begin{tabular}{|c|c|c|c|c|c|c|}
\hline $\begin{array}{l}\text { Case } \\
\text { no. }\end{array}$ & $\begin{array}{l}\text { Age } \\
(m)\end{array}$ & Sex & Length of convulsions & $\begin{array}{l}\text { Diagnosis of cause of } \\
\text { fever before } L P\end{array}$ & $\begin{array}{l}\text { CSF white cell count } \\
\mathrm{mm}^{3}\left(\times 10^{9} / l\right)\end{array}$ & $\begin{array}{l}\text { Growth on CSF } \\
\text { culture }\end{array}$ \\
\hline 1 & 8 & $\mathbf{M}$ & $5 \mathrm{~min}$ & Cause unknown & $\begin{array}{l}1000(1 \cdot 0) \\
(100 \% \text { lymphocytes })\end{array}$ & Mumps virus \\
\hline 2 & 15 & $\mathbf{M}$ & $1 \mathrm{~min}$ & Throat infection & $\begin{array}{l}475(0.48) \\
(97 \% \text { lymphocytes })\end{array}$ & $\begin{array}{l}\text { Nil (presumed } \\
\text { viral) }\end{array}$ \\
\hline 3 & 14 & $\mathbf{M}$ & A few min & $\begin{array}{l}\text { Upper respiratory tract } \\
\text { infection }\end{array}$ & $\begin{array}{l}1660(1 \cdot 7) \\
(80 \% \text { lymphocytes })\end{array}$ & $\begin{array}{l}\text { Nil (presumed } \\
\text { viral) }\end{array}$ \\
\hline 4 & 12 & $\mathbf{M}$ & $\begin{array}{l}3 \text { convulsions lasting a few, } \\
10 \text {, and } 15 \text { minutes }\end{array}$ & $\begin{array}{l}\text { Upper respiratory tract } \\
\text { infection }\end{array}$ & $\begin{array}{l}1700(1 \cdot 7) \\
(100 \% \text { polymorphs })\end{array}$ & $\begin{array}{c}\text { Haemophilus } \\
\text { influenzae }\end{array}$ \\
\hline
\end{tabular}

Calcium. This was estimated in 232 children (71\%). The mean level was $9 \cdot 6 \pm 0 \cdot 7 \mathrm{mg} / 100 \mathrm{ml}(2 \cdot 4 \pm 0 \cdot 18$ $\mathrm{mmol} / \mathrm{l})$, the normal range for the method being $8 \cdot 5-10 \cdot 5 \mathrm{mg} / 100 \mathrm{ml}(2 \cdot 1-2 \cdot 6 \mathrm{mmol} / \mathrm{l})$. The highest level, $11.0 \mathrm{mg} / 100 \mathrm{ml}(2 \cdot 8 \mathrm{mmol} / \mathrm{l})$, was found in 2 children who were not investigated further. 8 children had plasma calcium levels below $8.5 \mathrm{mg} / 100 \mathrm{ml}(2 \cdot 1 \mathrm{mmol} / \mathrm{l})$, and in 4 of these the level was below $8 \cdot 0 \mathrm{mg} / 100 \mathrm{ml}(7 \cdot 9,7 \cdot 8,6 \cdot 6$, and $5 \cdot 2 \mathrm{mg} / 100 \mathrm{ml} ; 2,2,1 \cdot 7,1 \cdot 3 \mathrm{mmol} / \mathrm{l})$. The cause of the hypocalcaemia in these 4 children was not determined. In 2 cases further investigations showed normal calcium levels, and rickets was excluded. Another child has a normal phosphate level and was not investigated further, and the fourth child was lost to follow-up. No child with rickets was identified.

Serum electrolytes. Potassium was measured in 166 children $(51 \%)$. The mean value was $4.3 \pm 0.6$ $\mathrm{mmol} / 1(4.3 \pm 0.6 \mathrm{mEq} / \mathrm{l})$ with a range of $3 \cdot 0-6 \cdot 5$ $\mathrm{mmol} / \mathrm{l}$. Sodium was estimated in 163 children $(50 \%)$. The mean value was $135 \pm 4 \mathrm{mmol} / \mathrm{l}(135 \pm 4$ $\mathrm{mEq} / \mathrm{l})$ with a range of $125-145 \mathrm{mmol} / \mathrm{l}$. No case of hypernatraemic dehydration was identified. 14 children $(8 \%)$ had sodium levels in the range 125 $129 \mathrm{mmol} / \mathrm{l}$, but this group with mild hyponatraemia differed in no way from those with normal sodium levels.

Blood urea. Out of the 146 children $(45 \%)$ in whom blood urea was estimated, 7 had levels above 40 $\mathrm{mg} / 100 \mathrm{ml}(6.6 \mathrm{mmol} / \mathrm{l})$. They had all had typical febrile convulsions and they were not clinically dehydrated. The children with the highest values (84 and $63 \mathrm{mg} / 100 \mathrm{ml} ; 14$ and $10 \mathrm{mmol} / \mathrm{l}$ ), had normal blood urea levels when these were repeated at the same admission. The other 5 had levels from 41 to $58 \mathrm{mg} / 100 \mathrm{ml}(6 \cdot 8-9 \cdot 6 \mathrm{mmol} / \mathrm{l})$, but these were not repeated. No child with chronic renal disease was identified.

\section{Discussion}

The children in our study were similar in age, sex, and cause of fever to those in other large series of febrile convulsions (Lennox-Buchthal, 1973). The purpose of performing investigations routinely in children with their first febrile convulsion is to identify an underlying disorder which may have contributed to the convulsion but which is not apparent on taking a history and examining the child.

It is well recognized that children with meningitis are liable to convulse (Ounsted, 1951). In the 2-year period of our survey, 87 children were admitted to hospital and found to have meningitis. 24 of these $(27 \%)$ had convulsions and 14 of these $(16 \%)$ actually presented because of the convulsion. 8 had signs of meningitis such as neck stiffness or a bulging fontanelle, though such signs were not always obvious. Our policy of performing lumbar punctures routinely in children with their first febrile convulsion resulted in the detection of 4 cases of meningitis, one of which was bacterial. Presumably it would not have mattered if the $\mathbf{3}$ cases of viral meningitis had remained undetected. 318 lumbar punctures were performed to detect this single case of bacterial meningitis. On the other hand, routine lumbar puncture was normal in 2 children who shortly afterwards developed meningococcal meningitis, and though in these cases there was no delay in repeating the investigation when signs of meningitis appeared, it could easily have given the observers a false sense of security.

It is obviously desirable to reduce the numbers of lumbar punctures performed without seriously reducing the chances of detecting meningitis. A review of our cases of bacterial meningitis over a 2-year period showed that those over 18 months of age had unequivocal signs of meningitis, but that those children who were less than 18 months often had only a slight suspicion of neck stiffness or a bulging fontanelle. If lumbar punctures had been routinely 
confined to children less than 18 months old with their first febrile convulsion the 4 cases of meningitis would still have been detected. It would not be sufficient to limit lumbar punctures to those children who did not have a cause for their fever, since children with bacterial meningitis may have coexistent upper respiratory tract infections (Samson et al., 1969).

The other investigations were very unhelpful. 3 cases of mild to moderate iron deficiency anaemia were detected and treated. The children were asymptomatic and it could be argued that to perform 309 haemoglobin estimations to detect these 3 cases of anaemia was not justified. It is difficult to assess the value of white blood counts in a retrospective survey, but it is our impression that they did not influence the decision to use or withhold antibiotic therapy.

One child had low blood glucose on admission, but no symptoms of hypoglycaemia and has had no episodes of hypoglycaemia since then. Bamberger and Matthes (1959) reviewed the literature and concluded that there was no relationship between febrile convulsions and hypoglycaemia. It would be wise, however, to exclude hypoglycaemia, using Dextrostix, in any child brought to hospital unconscious. Hyperglycaemia has been noted previously (Spirer et al., 1974; Rutter and Smales, 1976)this is a temporary, self correcting phenomenon and is therefore not a useful observation.

Hypocalcaemia due to infantile rickets used to predispose children to febrile convulsions (Herlitz, 1941) but this was not found to be a factor in recent series (Lennox-Buchthal, 1973). We did not identify a child with rickets, but it might be worth performing calcium, phosphate, and alkaline phosphatase estimations in children of Asian immigrants who present with a febrile convulsion.

Hypernatraemic dehydration is associated with convulsions, but in our study no cases presented as a febrile convulsion. Mild hyponatraemia was common and unexplained. The hyponatraemic children had no special features and measurement of serum sodium was not of use in the diagnosis and treatment of any of the children. Serum potassium measurements, too, were not useful.

We suggest that children admitted to hospital with their first febrile convulsion who are under 18 months of age should have a lumbar puncture to exclude meningitis regardless of whether they have no signs of meningitis or definite signs of an infection elsewhere. Other investigations need not be performed routinely unless clinically indicated.

We thank Mrs. Sally Woodward for secretarial help.

References

Asnes, R. S., Novick, L. F., Nealis, J., and Nguyen, M. (1975). The first febrile seizure: a study of current pediatric practice. Journal of Pediatrics, 87, 485-488.

Bamberger, P., and Matthes, A. (1959). Anfälle im Kindesalter, p. 573. Karger, Basel.

Herlitz, G. (1941). Studien über die sogenannten initialen Fieberkrämpfe bei Kindern. Acta Paediatrica Scandinavica, 29, Suppl. 1 .

Lennox-Buchthal, M. A. (1973). Febrile convulsions-a reappraisal. Electroencephalography and Clinical Neurophysiology, Suppl. 32.

Livingston, S. (1970). Seizure disorders. Current Pediatric Therapy, 4, p. 129. Ed. by S. S. Gellis and B. M. Kagan. Saunders, Philadelphia.

Ounsted, C. (1951). Significance of convulsions in children with purulent meningitis. Lancet, 1, 1245-1248.

Rutter, N., and Smales, O.R.C. (1976). Calcium, magnesium, and glucose levels in blood and C.S.F. of children with febrile convulsions. Archives of Disease in Childhood, 51, 141-143.

Samson, J. H., Apthorp, J., and Finley, A. (1969). Febrile seizures and purulent meningitis. Journal of the American Medical Association, 210, 1918-1921.

Spirer, Z., Weisman, J., Yurman, S., and Bogair, N. (1974). Hyperglycaemia and convulsions in children. Archives of Disease in Childhood, 49, 811-813.

Correspondence to Dr. N. Rutter, Department of Child Health, University Medical School, Clifton Boulevard, Nottingham NG7 2UH. 